\title{
Influence of Harvest Date and Grape Variety on Sensory Attributes and Aroma Compounds in Experimental Icewines of Ukraine
}

\author{
Viktoriia Lutskova *(D) and Irina Martirosyan \\ Department of Commodity Science and Customs, Odessa National Academy of Food Technologies, Kanatna \\ Street 112, 65039 Odessa, Ukraine; miaviva@ukr.net \\ * Correspondence: ostapenkoviktoriya7@gmail.com; Tel.: +380-956133962
}

\begin{abstract}
Icewine is a sweet dessert wine whose sensory and chemical attributes are caused by technology peculiarities including the special climatic conditions and acceptable grape varieties. This study aimed to evaluate the sensory characteristics and aromatic compounds in experimental icewines produced from the grape varieties Rkatsiteli, Telti kuruk, Marselan, and Moldova that had been picked in the Odessa region at temperatures of at least minus $7^{\circ} \mathrm{C}$ during the 2015 (H1) and 2016 (H2) harvests. Sensory attributes were determined by trained experts, and descriptors for icewines were chosen by consensus. A total of 33 aromatic compounds including 12 that exceeded the threshold were identified using chromatographic analysis. Rkatsiteli icewine obtained from H1 was characterized by the highest concentration of geraniol, 1-octanol, and 2-phenyl acetate, influencing the pronounced citrus and sweet fruit aromas in sensory profiles. The highest concentrations of ethyl hexanoate and ethyl octanoate associated with aromas of dried fruits were detected in Moldova and Marselan icewines made from H2. No 1-hexanol and benzyl alcohol were found in Rkatsiteli and Telti kuruk icewines. Only Moldova and Marselan icewines had $\gamma$-nonalactone and benzaldehyde, respectively. Sensory parameters and the quantity of aromatic compounds of Ukrainian experimental icewines depended on harvest date and grape varieties.
\end{abstract}

Citation: Lutskova, V.; Martirosyan, I Influence of Harvest Date and Grape Variety on Sensory Attributes and Aroma Compounds in Experimental Icewines of Ukraine. Fermentation 2021, 7, 7. https://doi.org/10.3390/ fermentation7010007

Received: 29 November 2020

Accepted: 4 January 2021

Published: 6 January 2021

Publisher's Note: MDPI stays neutral with regard to jurisdictional clai$\mathrm{ms}$ in published maps and institutional affiliations.

Copyright: (C) 2021 by the authors. Licensee MDPI, Basel, Switzerland. This article is an open access article distributed under the terms and conditions of the Creative Commons Attribution (CC BY) license (https:// creativecommons.org/licenses/by/ $4.0 /)$.

\section{Introduction}

Icewine is a sweet dessert wine obtained from frozen grapes. The most important indicators of the possibility of icewine production by the natural freezing of grapes are the presence of suitable low temperatures and cold-resistant cultivars. In Canada, winemakers are allowed to harvest grapes with a required sugar concentration of a minimum of $32^{\circ}$ Brix at a temperature below or equal to minus $8^{\circ} \mathrm{C}[1]$, according to rules of International Organisation of Vine and Wine (OIV) - at a temperature below or equal to minus $7^{\circ} \mathrm{C}$ with a grape sugar content minimum of 25 Brix [2]. Rkatsiteli, Telti kuruk, Marselan, and Moldova grown in the south of Ukraine were chosen in this work due to their ampelographic characteristics acceptable for icewine grapes, on the one hand, and for the purpose of studying their winter hardiness in the climatic conditions of the area, on the other hand.

Rkatsiteli, due to its genetic characteristics, has a thick white skin that meets the requirements of grape varieties for icewine [3]. In addition to the late maturation and thick dark skin, the uniqueness of the Marselan variety lies in the limited study of its parameters, which impacts its research in icewine technology [4]. Marselan originated from the cross-breeding of Cabernet Sauvignon and Grenache in France [5]. Another dark-skinned grape variety, Moldova, is resistant to many diseases of grapes, which is also one of the conditions for leaving the vine before the first frosts [6]. Telti kuruk is a late ripening and an autochthonous white grape variety of Ukraine [6]. It should be noted that Riesling and Vidal are the most commonly used cultivars in icewine production in Canada [7]. 
The influence of temperature on the composition and quality of grapes and wines has been studied by numerous researchers [8-11]. It is important to note that no significant climatic changes can affect grape mechanical properties, which absolutely impacts wine technology, and hence the quality of the wine $[10,11]$. The icewine technology of the natural freezing of grapes depends on the frost resistance of the grape variety and the presence of minus temperatures, which should be in the range from minus 7 to minus $12{ }^{\circ} \mathrm{C}[2,4,5,12]$. Agroclimatic factors determine the possibility of frozen grape harvesting, namely, the absence of frost or the grape unsuitability to withstand a long season before the first frosts pose the greatest risk [13]. Therefore, the natural method of freezing grapes is difficult with respect to accurately predicting the weather, as well as harvesting grapes before sunrise, which affects the complexity of the technology. The study of the peculiarities of the Northern Black Sea Coast, including the Odessa region, as a region with the necessary resources to implement the comprehensive development of winemaking and viticulture, is the aim of the investigations of Ukrainian scientists [14,15]. However, the meteorological conditions of the Northern Black Sea Coast of Ukraine, as a wine-growing and viticulture territory, have not been sufficiently studied to ensure the development of icewine production.

The main groups of aromatic compounds of icewine are higher and terpene alcohols, esters, acetates and acetals, aromatic aldehydes and ketones, lactones, and volatile phenolic acids [16-18]. Many factors can impact the wine quality including the grape variety, yeasts, winemaking techniques, harvest date, and chemical compositions [16-23]. Ethyl benzoate, ethyl octanoate, ethyl hexanoate, isoamyl acetate, and 2-phenyl acetate create honey and fruit aromas, the intensity of which is influenced by the method of freezing grapes [17]. Thus, depending on the grape variety and the date of collection in the frozen state, the mass concentrations of esters can vary in significant ranges: 1.3-1105 $\mu \mathrm{g} / \mathrm{L}$ [20-22]. Most researchers identified compounds responsible for the aroma of dried fruits and honey in icewines [20-23]. Analysis of the chromatographic investigations of volatile aromatic substances shows that the concentrations of isoamyl acetate, hexyl acetate, ethyl 2-methylbutyrate, ethyl 3-methylbutyrate, as well as linalool and cis-rose oxide, differ significantly in wines obtained from the use of different strains of yeast $[2,21,23]$.

The study of the organoleptic characteristics of icewines is of particular interest. Research on the sensory properties of wines made by different methods of freezing grapes shows a difference in the intensity of citrus and floral aromas [20-22], and the perceptible aromas of dried fruits in icewines indicate the maturation of grapes on the vine [18]. Intense aromas of apricot, honey, and pineapple create the aromatic profile of Canadian ice wines [24,25], and descriptors of tropical fruits, caramels, and roses are typical for icewines from China [18-20]. In addition, floral, chemical, pungent, and ripe fruit aromas were found in Gewürztraminer icewines from Croatia [17]. Thus, the physicochemical and organoleptic properties of icewines can differ significantly depending on the grape variety, harvest dates, growing area, method of freezing grapes, and yeast strain.

The aim of the current work was to determine the sensory attributes and aromatic compounds of experimental icewines produced under climate conditions in the south of Ukraine depending on the harvest date and grape variety.

\section{Materials and Methods}

\subsection{Grapes}

The experimental icewines made from Rkatsiteli, Telti kuruk, Marselan, and Moldova grapes were harvested twice from vineyards of the "Industrial-Trading Company Shabo" Ltd. in Odessa region: 30 December of 2015 (H1) and 4 January of 2016 (H2). Rkatsiteli, Telti kuruk, Marselan, and Moldova grown in the south of Ukraine were chosen in this work due to their ampelographic characteristics acceptable for icewine grapes, on the one hand, and for the purpose of studying their winter hardiness under the climatic conditions of the area, on the other hand. The characteristics of the grape varieties used are shown in Table 1. The grapes were picked when the air temperature was lower than minus $7{ }^{\circ} \mathrm{C}$ according to the definition of the vitivinicultural products code sheet of OIV [1]: minus $7.5^{\circ} \mathrm{C}$ for 
$\mathrm{H} 1$ and minus $12{ }^{\circ} \mathrm{C}$ for $\mathrm{H} 2$. These dates were chosen to obtain the minimum required level of sugar of at least $25^{\circ} \mathrm{Brix}$ and to determine the contributions to the diversity of icewine composition including the quantity of the aromatic compounds. In addition, the temperatures were the lowest and the highest ones during the icewine crop growth period. Grapes were pressed by cultivar using a pneumatic press with periodic action of the closed type, i.e., BucherPlus (Bucher, Niederweningen, Switzerland).

Table 1. Description of grape variety, maturation, and species of Vitis.

\begin{tabular}{|c|c|c|}
\hline Grape Variety & Maturation Period, Days [6] & The Origin of Grapes and a Brief Ampelographic Description \\
\hline Rkatsiteli & Late maturing, 155-170 & $\begin{array}{l}100 \%-V \text {. vinifera. Technical white grape variety. The cluster is small, long, } \\
\text { conical. The berry is round or oval. The skin is thin, very strong. The flesh } \\
\text { is juicy. The variety is moderately resistant to mildew, weakly affected by } \\
\text { gray rot, resistance to powdery mildew is low. Frost resistance is moderate. }\end{array}$ \\
\hline Telti kuruk & Late maturing, $155-160$ & $\begin{array}{l}100 \%-V \text {. vinifera. Technical white grape variety. Bunch of medium size, } \\
\text { elongated-cylindrical-conical. Berry of medium size or small, slightly oval, } \\
\text { yellowish-green, with a thick waxy coating. The skin is thin, strong. The } \\
\text { pulp is juicy. Frost resistance is under study. }\end{array}$ \\
\hline Marselan & Late maturing, 170-190 & $\begin{array}{l}100 \% \text {-V. vinifera. Technical red grape variety. Crossing scheme: Cabernet } \\
\text { Sauvignon and Grenache. The cluster is small. The berry is round, small. } \\
\text { The skin is thick, very strong. The pulp is juicy. The variety is resistant to } \\
\text { fungal diseases. Frost resistance is under study. }\end{array}$ \\
\hline Moldova & Late maturing, 155-180 & $\begin{array}{l}56.19 \%-V \text {. vinifera, } 3.13 \%-V \text {. labrusca, } 29 \%-V \text {. rupestris, } 6.25 \%-V \text {. } \\
\text { berlandieri, } 5.28 \%-V \text {. lincecumii. Table red grapes. Hybrid, crossbreeding } \\
\text { scheme: Guzal kara x Save Villar } 12-375 \text {. The cluster is large, } \\
\text { medium-dense. The berry is large, oval. The skin is thick, the pulp is juicy. } \\
\text { The variety is resistant to mildew and gray rot. Frost resistance is high. }\end{array}$ \\
\hline
\end{tabular}

\subsection{Wines}

All samples of icewines were produced consistently with the proposed technology described by Lutskova V. [26]. The effective fining before fermentation musts was achieved using Microcol bentonite alpha (Laffort Co., Bordeaux, France) with concentration of $1 \mathrm{~g} / \mathrm{L}$ and Polylact (Laffort Co., Bordeaux, France). The addition of Assotan (Esseco SRL, San Martino, Italy) was for antioxidant process. All samples of musts were formerly heated up to $18-20^{\circ} \mathrm{C}$ and then they were inoculated with Saccharomyces cerevisiae VIN 2000 hybrid (Anchor, Cape Town, South Africa) at rate of $5 \mathrm{~g} /$ dal. Before fermentation, the following procedures were conducted: the rehydration of yeast to the intended concentration of $5 \mathrm{~g} /$ dal; then, after $15 \mathrm{~min}$ of rehydration, an equal volume of yeast and must previously heated to $28^{\circ} \mathrm{C}$ was mixed and left for $1 \mathrm{~h}$. In this starter, an equal volume of sweet must was added and left at a temperature of $25^{\circ} \mathrm{C}$, stirring every $45 \mathrm{~min}$. The yeast starter was added as follows: on the 1st day of fermentation, after two days of fermentation, and after one week for acclimatization and accumulation of yeast biomass. In order to reduce the fermentation time and increase the rate of process, a complete fermentation activator and the yeast nutrient Maxaferm (DSM Food Specialties B.V, Delft, The Netherlands) at a concentration of $2 \mathrm{~g} /$ dal and Booster Blanc (Lallemand, Montréal, QC, Canada) at a concentration of $3 \mathrm{~g} /$ dal were simultaneously added to musts after two days of fermentation. The aforementioned nutrients were diluted in water, 1:10, and added once. With the achievement in wine materials of an ethyl alcohol content of 9-10\% vol. on the 8th day, fermentation was stopped by cooling the wine material at a temperature of minus $5{ }^{\circ} \mathrm{C}$. The complex system of wine stabilization for icewines, including the use of Erbsloeh PVPP (Erbsloh, Geisenheim, Germany) based on Polyvinylpolypyrrolidone, Neoclar AF (Enogroup, Kishinev, Moldova), composed of gelatin, bentonite, and charcoal with subsequent cold treatment at minus $4-6{ }^{\circ} \mathrm{C}$ for $4-6$ days was utilized. To ensure correct preservation of icewines, $75 \mathrm{mg} / \mathrm{L}$ of sulphur dioxide (Laffort, Bordeaux, France) was 
added. To achieve bottling-ready icewines, they were processed in accordance with the "Technological instructions for the processing of wine materials in the wine industry" TI U 37471967-11.02.11 [27]. Then, the icewines were stored for no less than 20-25 days and bottled.

\subsection{Chemical Methods}

Chemical analysis was carried out according to the prevailing laws of winemaking of Ukraine and international documentation regarding icewine production. The sugar content of musts was measured by a Digital Hand-Held "Pocket" Refractometer PAL1 (Atago Co., Ltd., Fukaya-shi, Japan) and then converted from Brix into g/L using a table giving the sugar content of musts and concentrated musts in grams per liter, recommended by OIV [28]. The $\mathrm{pH}$ of musts and icewines was determined by a pH-meter S220 (MettlerToledo International Inc., Columbus, OH, USA). The concentrations of titrated acid (TA) and volatile acidity (VA) were determined in accordance with standard methods [29].

Determination of aromatic compounds in the experimental icewines was conducted according to a method developed by specialists of the "Industrial-trading company Shabo" Ltd. using a gas chromatograph, Agilent Technology 7890 A (Agilent Technologies, Inc., Santa Clara, CA, USA). The main characteristics were a silica capillary column VF-WAXms $60 \mathrm{~m}$, the carrier gas was helium at a rate of $3 \mathrm{~mL} / \mathrm{min}$, column diameter-0.33 $\mathrm{mm}$, the temperature of the evaporator and the detector was $245^{\circ} \mathrm{C}$, the temperature of the thermostat ranged from 450 to $245{ }^{\circ} \mathrm{C}$ with a rate of $40 / \mathrm{min}$, sample volume- $1 \mathrm{mcl}$. Method principle: $0.05 \mathrm{~mL}$ of internal standard solution pentanol- $1(23.54 \mathrm{mg} / \mathrm{mL})$ was added to $10 \mathrm{~mL}$ of wine in a vial with a sealed stopper and actively mixed for $1-2 \mathrm{~min}$. Then, $0.2 \mathrm{~mL}$ of chloroform was introduced and the contents mixed for 2 min until emulsions formed. The vial was centrifuged for $5 \mathrm{~min}$ at $3000 \mathrm{rpm}$. Then, the resulting chloroform extract (at the bottom of the vial) was transferred into a chromatographic vial with a glass micro-insert of $0.25 \mathrm{~mL}$. The extract was analyzed by a chromatograph mass spectrometry detector 5973. The concentrations of compounds were calculated as the ratio of the peak areas of volatile substances relative to the internal standard peaks without correction factors. The aromatic components were identified by comparison of retention times of the substances obtained in the chromatogram and the standard library of mass spectra (Nisto2) relative to pure standards. The aforementioned method was performed on all icewine samples in triplicate. Chemical standards were purchased from Sigma-Aldrich (Oakville, ON, Canada), Aldrich (Oakville, ON, Canada), Bedoukian (Danbury, CT, USA), and Acros Organics (Geel, Belgium) (Table 2).

Table 2. Chemical standards and quantitative and qualitative ions for analyzed icewine samples.

\begin{tabular}{cccccc}
\hline Cas Number & Compound & Supplier & $\begin{array}{c}\text { Quantification } \\
\text { Ion }(\mathrm{m} / \mathbf{z})\end{array}$ & $\begin{array}{c}\text { Qualitative } \\
\text { Ions }(\mathrm{m} / \mathbf{z})\end{array}$ & Odor Characteristics \\
\hline $111-27-3$ & 1-Hexanol & Sigma-Aldrich & 56 & 69,84 & Leaf, grassy, resin, medicinal \\
\hline $78-83-1$ & Isobutanol & Aldrich & 43 & $42,41,74$ & Fruity, floral \\
\hline $71-23-8$ & 1-Propanol & Sigma-Aldrich & 31 & 59,42 & Sweet, fruit \\
\hline $3391-86-4$ & 1-Octen-3-ol & Acros Organics & 57 & $72,85,99$ & Mushroom \\
\hline $98-55-5$ & a-Terpineol & Aldrich & 59 & 75,63 & Lilac, citrus, lime \\
\hline $100-51-6$ & Benzyl alcohol & Aldrich & 79 & 85,93 & flower, fruit \\
\hline $543-49-7$ & 2-heptanol & Aldrich & 58 & 73,87 & lemon, citrus \\
\hline $111-87-5$ & 1-octanol & Sigma-Aldrich & 56 & $41,69,84$ & rose, citrus \\
\hline $60-12-8$ & Phenylethyl Alcohol & Aldrich & 91 & $122,65,51$ & Burnt, rose, oily, honey \\
\hline $106-24-1$ & Geraniol & Aldrich & 90 & 41,66 & Citrus \\
\hline $106-22-9$ & Citronellol & Aldrich & 55 & $41,67,156$ & Rose, citrus \\
\hline
\end{tabular}


Table 2. Cont.

\begin{tabular}{|c|c|c|c|c|c|}
\hline Cas Number & Compound & Supplier & $\begin{array}{l}\text { Quantification } \\
\text { Ion }(m / z)\end{array}$ & $\begin{array}{l}\text { Qualitative } \\
\text { Ions }(m / z)\end{array}$ & Odor Characteristics \\
\hline $78-70-6$ & Linalool & Sigma-Aldrich & 71 & $93,121,154$ & Lemon, flower \\
\hline $123-92-2$ & Isoamyl acetate & Aldrich & 43 & $70,55,87$ & Pear \\
\hline $123-66-0$ & Ethyl hexanoate & Aldrich & 88 & $99,60,144$ & Fruity, apple \\
\hline $7452-79-1$ & $\begin{array}{l}\text { Ethyl 2-methyl } \\
\text { butyrate }\end{array}$ & Aldrich & 57 & $102,74,130$ & Blackberry, pineapple \\
\hline $105-54-4$ & Ethyl butyrate & Aldrich & 71 & $43,88,116$ & Blackberries, tropical fruits \\
\hline $108-64-5$ & $\begin{array}{c}\text { Ethyl 3-methyl } \\
\text { butyrate }\end{array}$ & Aldrich & 88 & $41,70,130$ & Berry, cherry \\
\hline $106-32-1$ & Ethyl octanoate & Aldrich & 88 & $101,127,172$ & pomegranate, pineapple, peach \\
\hline $103-45-7$ & 2-Phenethyl acetate & Aldrich & 104 & $43,91,78$ & Ripe fruit, floral \\
\hline $110-38-3$ & Ethyl decanoate & Aldrich & 88 & $101,73,155$ & Sweet, herbal \\
\hline 93-89-0 & Ethyl benzoate & Aldrich & 105 & $122,77,172$ & Chamomile, flower, celery, fruit \\
\hline $142-62-1$ & Hexyl acetate & Aldrich & 60 & $56,84,69$ & Apples, pears, cherries \\
\hline $4455-13-4$ & Ethyl acetate & Aldrich & 30 & 44,68 & Pear, fruit \\
\hline 98-01-1 & Furfural & Aldrich & 96 & $67,42,51$ & Bread, pastries \\
\hline $100-52-7$ & Benzaldehyde & Bedoukian & 46 & $85,93,98$ & Almonds \\
\hline $121-33-5$ & Vanillin aldehyde & Bedoukian & 45 & $73,79,85$ & Vanilla \\
\hline $97-53-0$ & Eugenol & Aldrich & 43 & 78,96 & Spicy cloves, spices, oak \\
\hline $142-62-1$ & Hexanoic acid & Aldrich & 60 & 45,68 & Fruit, herb \\
\hline $103-82-2$ & Phenylacetic acid & Aldrich & 60 & 56,46 & Honey \\
\hline $124-07-2$ & Octanoic acid & Aldrich & 60 & 78,81 & Oil \\
\hline $104-61-0$ & $\gamma$-nonalactone & Aldrich & 85 & $41,114,156$ & Oil, honey, coconut \\
\hline $2628-17-3$ & 4-vinylphenol & Aldrich & 150 & $54,97,110$ & Oak \\
\hline $7786-61-0$ & $\begin{array}{l}\text { 2-methoxy-4- } \\
\text { vinylphenol }\end{array}$ & Aldrich & 150 & 54,97 & Spices, cloves \\
\hline
\end{tabular}

\subsection{Sensory Analysis}

The panel of 10 experts took part in the sensory analysis of the icewines. All judges had had theoretical and practical training in similar research and were certified in wine tasting. In our work, the objective of the sensory analysis was to characterize the aroma and taste of icewines made in Ukraine.

The sensory analysis of the experimental icewines consisted of sessions that were performed at the end of February 2016. Sessions were divided into two main parts: 10 training sessions ( $1 \mathrm{~h}$ each) and direct evaluation of the organoleptic qualities of the proposed wines. Firstly, the training part involved questions of the main icewine sensory analyses worldwide. During the next training, experts were presented with a list of 95 wine terms obtained from the literature [30] in order to determine the prospective lexicon for icewine aroma and taste. In addition, the international standard ISO 5492:2008 «Sensory analysis-Vocabulary» was used. As a result, 12 terms describing aromatic sensations and five taste perceptions were chosen by panel consensus and then used in tasting sheets. The next stage included the general methods related to expert training in conformance with ISO 8586:2012 «Sensory analysis-General guidelines for the selection, training, and monitoring of selected assessors and expert sensory assessors». For taste/tactile training, water solutions with different concentrations of sugar (sweetness), tartaric acid (sourness), caffeine (bitterness), and aluminum potassium sulfate (astringency) were produced according to 
the method published by Jackson R. S. [31]. Different aromatic standards were produced by a chemical method that had been prepared prior to training [31]. In addition, an electronic wine nose «Le Nez Du Vin» was applied. In addition, various natural products including fruit and spices were used as taste and aroma standards. During the next training, three Riesling icewines from wineries Lion Gri, Cricova Zevs, Kvint (Moldova) and one from Shabo (Ukraine), Blaufränkisch, and Welschriesling icewines from Chateau Topolcianky (Slovakia) were evaluated for establishing the icewine type.

The experts determined the aroma and taste of icewine samples made from $\mathrm{H} 1$ and $\mathrm{H} 2$ in duplicate in the last session. All experts had been asked not to eat foods with strong intense aromas or flavors the day before. The samples of icewines were cooled until $10{ }^{\circ} \mathrm{C}$ and assigned three-digit codes before the tasting. Approximately $50 \mathrm{~mL}$ of a randomly selected sample was poured in a clean wine glass, and the tasting sheets were shown to each expert. Sensory attributes were quantified using a nine-point intensity scale (ISO 4121:2003 «Sensory analysis—Guidelines for the use of quantitative response scales») anchored from «1-low to 9-high». In the case of sensing another aroma or taste that had been not defined on the sheet, experts were allowed to add appreciate descriptors. Panelists evaluated each wine for $10 \mathrm{~min}$ with a 2-min break between samples. Water was provided for rinsing between icewines. After the evaluation of icewines, experts discussed and compared the obtained scores.

Testing and training sessions were conducted in a laboratory of sensory analysis in ONAFT equipped with individual booths, designed according to ISO 8589 (1988). The usual universal tasting glasses in accordance with ISO 3591:1977 «Sensory analysis-ApparatusWine-tasting glass» were used purchased from the Ukrainian branch of the Austrian company "Riedel".

\subsection{Statistical Analysis}

Statistical methods included Fisher's Least Significant Difference for mean separation at $p<0.05$. One-way Analysis of variance (ANOVA) was performed using XL STAT (Addinsoft, Paris, France). To evaluate panel performance, the degree of concordance and reliability was calculated [32]. All figures were drawn using Excel software (Microsoft Co., Redmond, WA, USA). Mean scores of significant sensory attributes $(p<0.05)$ were calculated in order to create cobweb diagrams. An independent sample $t$-test was calculated to compare the means of the sensory data of icewines.

\section{Results}

\subsection{Physicochemical Analysis}

Physicochemical attributes of icewines from frozen grapes largely depend on two processes: grape freezing and conditions of must fermentation [24,33]. The freezing of grapes contributes to increase the mass concentrations, not only of sugars in the grape berry, but also acids, phenolic, and aromatic compounds, which then affect the formation of the icewine organoleptic indicators [24]. According to the results, harvest date was an active factor in increasing the sugar content of both white and red grapes (Table 3). Marselan and Moldova musts had the same $\mathrm{pH}$ values depending on different harvest dates versus those of Rkatsiteli and Telti kuruk musts. A small difference in TA was found in Telti kuruk musts of both harvests. The TA of Rkatsiteli, Marselan, and Moldova musts obtained from $\mathrm{H} 2$ was characterized by lower values compared to $\mathrm{H} 1$.

The influence of harvest dates $(\mathrm{H} 1, \mathrm{H} 2)$ on chemical compositions of the varietal experimental icewines is shown in Table 4. All icewines samples had different residual sugar and ethanol depending on the harvest date. In icewines obtained from all grape varieties harvested in $\mathrm{H} 2$, the concentration of sugar and ethanol increased by 1-1.3 times. It should be noted that one of the features of icewines is a prolonged fermentation process, because the yeast is not able to immediately ferment the high sugar content into ethanol, indicating hyperosmotic shock $[2,16,17,24]$. In addition, values of VA play roles in icewine 
quality. The experimental icewines from $\mathrm{H} 1$ were characterized by lower values of VA compared to $\mathrm{H} 2$.

Table 3. Influence of harvest date (H1, H2) on the chemical compositions of grape musts.

\begin{tabular}{|c|c|c|c|}
\hline & H1 & $\mathrm{H} 2$ & Significance $^{a}$ \\
\hline \multicolumn{4}{|l|}{ Rkatsiteli musts } \\
\hline Brix & $29.5 a$ & $33.4 \mathrm{~b}$ & $* * *$ \\
\hline $\mathrm{pH}$ & $3.5 \mathrm{a}$ & $3.7 \mathrm{~b}$ & $* *$ \\
\hline Titratable acidity $(\mathrm{g} / \mathrm{L})$ & $8.9 \mathrm{a}$ & $8.4 \mathrm{~b}$ & $* *$ \\
\hline \multicolumn{4}{|l|}{ Telti kuruk musts } \\
\hline Brix & $30.0 \mathrm{a}$ & $35.7 \mathrm{~b}$ & $* * *$ \\
\hline $\mathrm{pH}$ & $3.4 \mathrm{a}$ & $3.6 \mathrm{~b}$ & * \\
\hline Titratable acidity $(\mathrm{g} / \mathrm{L})$ & $9.1 \mathrm{a}$ & $9.2 \mathrm{a}$ & ns \\
\hline \multicolumn{4}{|l|}{ Marselan musts } \\
\hline Brix & $28.5 \mathrm{a}$ & $35.2 b$ & $* * *$ \\
\hline $\mathrm{pH}$ & $3.8 \mathrm{a}$ & $3.8 \mathrm{a}$ & ns \\
\hline Titratable acidity $(\mathrm{g} / \mathrm{L})$ & $8.6 a$ & $8.0 \mathrm{~b}$ & $* * *$ \\
\hline \multicolumn{4}{|l|}{ Moldova musts } \\
\hline Brix & $29.2 a$ & $34.8 \mathrm{~b}$ & $* * *$ \\
\hline $\mathrm{pH}$ & $3.7 \mathrm{a}$ & $3.7 \mathrm{a}$ & ns \\
\hline Titratable acidity $(\mathrm{g} / \mathrm{L})$ & $9.1 \mathrm{a}$ & $8.5 b$ & $* *$ \\
\hline
\end{tabular}

Table 4. Influence of harvest date $(\mathrm{H} 1, \mathrm{H} 2)$ on the chemical compositions of the varietal experimental icewines.

\begin{tabular}{|c|c|c|c|}
\hline & H1 & H2 & Significance $^{a}$ \\
\hline \multicolumn{4}{|l|}{ Rkatsiteli icewines } \\
\hline Brix & $145.0 \mathrm{a}$ & $155.7 \mathrm{~b}$ & $* * *$ \\
\hline $\mathrm{pH}$ & $3.6 a$ & $3.7 \mathrm{~b}$ & $*$ \\
\hline Titratable acidity (g/L) & $9.0 \mathrm{a}$ & $8.6 b$ & $* *$ \\
\hline Ethanol $(\% \mathrm{v} / \mathrm{v})$ & $10.5 a$ & $11.0 \mathrm{~b}$ & $* *$ \\
\hline Volatile acidity $(\mathrm{g} / \mathrm{L})$ & $0.8 \mathrm{a}$ & $0.95 b$ & $* * *$ \\
\hline \multicolumn{4}{|l|}{ Telti kuruk icewines } \\
\hline Brix & $158.7 \mathrm{a}$ & $170.1 \mathrm{~b}$ & $* * *$ \\
\hline $\mathrm{pH}$ & $3.5 \mathrm{a}$ & $3.6 b$ & $*$ \\
\hline Titratable acidity $(\mathrm{g} / \mathrm{L})$ & $9.5 \mathrm{a}$ & $9.5 \mathrm{a}$ & ns \\
\hline Ethanol $(\% \mathrm{v} / \mathrm{v})$ & $10.2 \mathrm{a}$ & $11.6 b$ & $* * *$ \\
\hline Volatile acidity (g/L) & $0.85 a$ & $1.0 \mathrm{~b}$ & $* * *$ \\
\hline \multicolumn{4}{|l|}{ Marselan icewines } \\
\hline Brix & $142.6 \mathrm{a}$ & $164.3 b$ & $* * *$ \\
\hline $\mathrm{pH}$ & $3.8 \mathrm{a}$ & $3.9 \mathrm{~b}$ & $*$ \\
\hline Titratable acidity $(\mathrm{g} / \mathrm{L})$ & $9.0 \mathrm{a}$ & $8.5 b$ & $* * *$ \\
\hline Ethanol $(\% \mathrm{v} / \mathrm{v})$ & $9.6 \mathrm{a}$ & $10.3 b$ & $* * *$ \\
\hline Volatile acidity $(\mathrm{g} / \mathrm{L})$ & $0.8 \mathrm{a}$ & $0.9 \mathrm{~b}$ & $* *$ \\
\hline \multicolumn{4}{|l|}{ Moldova icewines } \\
\hline Brix & $144.0 \mathrm{a}$ & $158.2 b$ & $* * *$ \\
\hline $\mathrm{pH}$ & $3.7 \mathrm{a}$ & $3.7 \mathrm{a}$ & ns \\
\hline Titratable acidity $(\mathrm{g} / \mathrm{L})$ & $9.5 a$ & $8.4 \mathrm{~b}$ & $* * *$ \\
\hline Ethanol $(\% \mathrm{v} / \mathrm{v})$ & $9.7 \mathrm{a}$ & $10.5 b$ & $* * *$ \\
\hline Volatile acidity $(\mathrm{g} / \mathrm{L})$ & $0.8 \mathrm{a}$ & $0.95 b$ & $* * *$ \\
\hline
\end{tabular}




\subsection{Sensory Analysis}

Based on the results of the tasting, the concordance coefficient was determined by a statistical method to establish the degree of agreement of scores of the sensory analyses. The concordance coefficient was $0.91 \%$, which indicates a high degree of agreement among experts.

Dried apricot, melon, pineapple, fig, lemon, honey, raisin, caramel, spicy, and oxidized aromas were chosen by experts as aroma descriptors. In addition, they decided to add plum and cherry aromas as specific aromas for Marselan and Moldova wines [4]. Figure 1 reports the average values of the aroma descriptors and tastes of the analyzed wine samples that were significant between $\mathrm{H} 1$ and $\mathrm{H} 2$ within a certain cultivar (at $p \leq 0.05$ ). The sensory analysis showed that aromas of honey and raisin were characterized for all wines but differed depending on the harvest date. Notable melon, pineapple, and caramel aromas were in the Rkatsiteli icewine of $\mathrm{H} 2$. The most perceived oxidized aromas of fig were from wine samples produced from Telti kuruk, but general sweetness was not significant. In addition, a spicy aroma was detected only in Telti kuruk icewines. The aromas of cherry and plum were determined only in icewines obtained from dark-skinned grape varieties. The aroma of dried apricot was characteristic for Rkatsiteli and Marselan icewines. Tastes such as bitterness and astringency were not perceived by the panel.

Rkatsiteli icewines

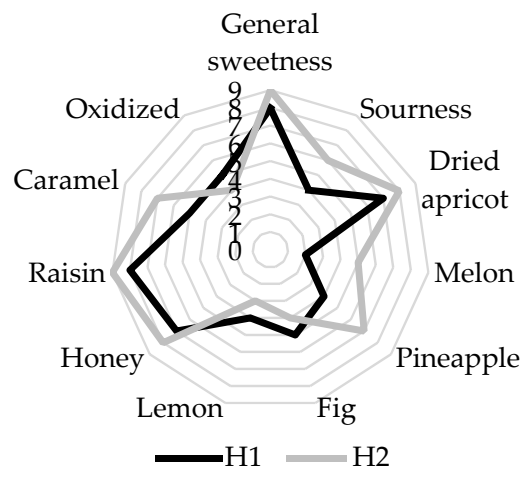

Marselan icewines

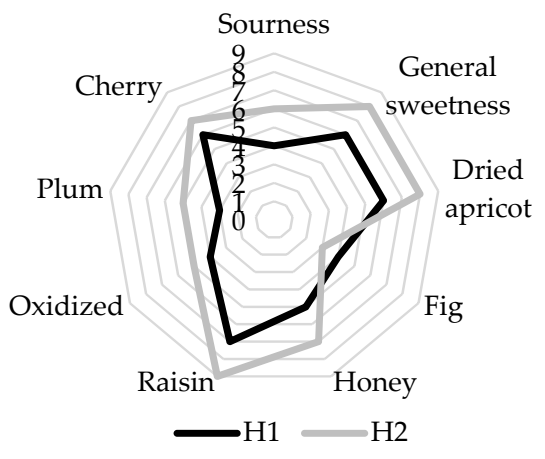

Telti kuruk icewines

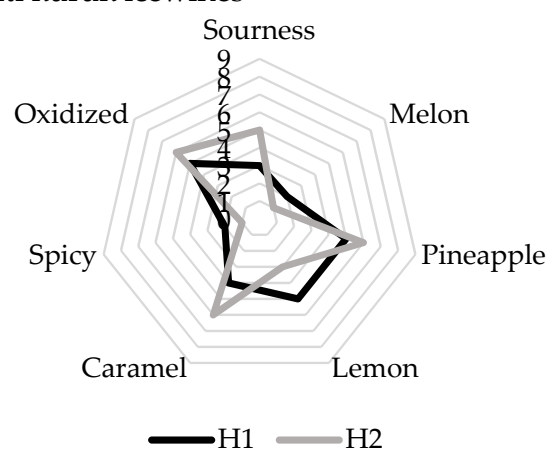

Moldova icewines

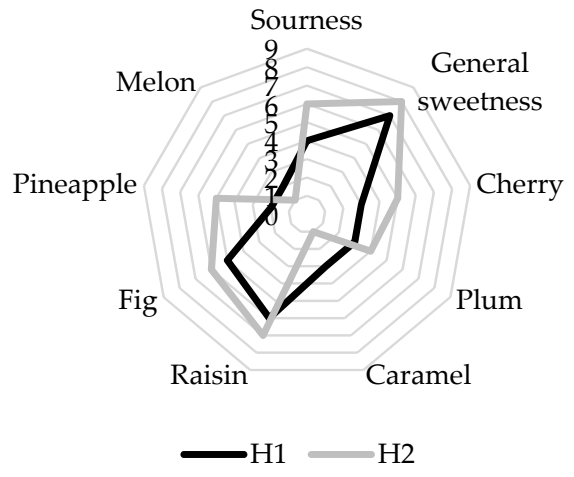

Figure 1. The intensity of sensory descriptors found in icewines made from four different varieties harvested at two different times. Sensory descriptors not shown on the plot are not significant according to a $t$-test.

\subsection{Aroma Compounds \\ 3.3.1. Odor Activity}

According to chromatographic analysis, 33 aromatic compounds belonging to the following groups were found in ice wines: ethyl esters and acetates, responsible for fruit and berry aromas, higher and terpene alcohols - for floral, citrus and honey aromas, and aromatic acids and aldehydes - provide nuts and shades of tropical fruits (Tables 5 and 6). In icewines of both harvests, the concentrations of isoamyl acetate, 2-phenyl acetate, and 
1-propanol responsible for honey and ripe fruit aromas were higher than the odor threshold. In Rkatsiteli icewines produced from H1, the concentration of geraniol was equal to the odor threshold characterized by citrus aromas. The highest odor activity of ethyl hexanoate and ethyl octanoate associated with aromas of dried fruits was detected in Moldova and Marselan icewines. The concentrations of ethyl 3-methyl butyrate were higher than the odor threshold in all experimental icewines. Among acid groups, only hexanoic acid, in all wine samples, had the highest odor threshold.

\subsubsection{Aroma Components}

Quantitative data of aromatic compounds in Rkatsiteli and Telti kuruk icewines are presented in Table 5. Wines obtained from H1 differed from ones of H2. The higher and terpene alcohols were identified as the biggest quantity aroma group among aroma volatiles. Esters and acetates accounted for $20 \%$ and $14 \%$, respectively, of the total quantity of aromatic compounds. No 1-hexanol and benzyl alcohol were found in Rkatsiteli and Telti kuruk icewines. Telti kuruk icewine of $\mathrm{H} 1$ did not have ethyl benzoate and hexyl acetate. The aldehydes and acids had the same values in icewine samples.

Table 5. Quantitative data of aromatic compounds in Rkatsiteli and Telti kuruk icewines.

\begin{tabular}{|c|c|c|c|c|c|c|c|}
\hline \multirow{2}{*}{ Compound } & \multicolumn{2}{|c|}{ Rkatsiteli } & \multirow{2}{*}{ Significance $^{a}$} & \multicolumn{2}{|c|}{ Telti Kuruk } & \multirow{2}{*}{ Significance $^{a}$} & \multirow{2}{*}{ Threshold $(\mu \mathrm{g} / \mathrm{L})$} \\
\hline & H1 & H2 & & H1 & $\mathrm{H} 2$ & & \\
\hline \multicolumn{8}{|c|}{ Higher and terpene alcohols } \\
\hline Isobutanol & $1260.11 \mathrm{a}$ & $1260.74 a$ & ns & $2120.41 a$ & $3260.3 b$ & $* * *$ & $40,000[34]$ \\
\hline 1-Propanol & $129.52 \mathrm{a}$ & $139.71 b$ & $* *$ & $150.7 \mathrm{a}$ & $200.2 b$ & $* * *$ & $120[34]$ \\
\hline 1-Octen-3-ol & $2.5 \mathrm{a}$ & $2.5 \mathrm{a}$ & ns & $1.5 \mathrm{a}$ & $3.0 \mathrm{~b}$ & * & $1[35]$ \\
\hline$\alpha$-Terpineol & $30.18 \mathrm{a}$ & $35.32 b$ & $* * *$ & $80.11 \mathrm{a}$ & $85.46 \mathrm{~b}$ & $* *$ & $250[36]$ \\
\hline Isoamyl alcohol & nd & $560.26 b$ & $* *$ & $300.5 \mathrm{a}$ & $570 \mathrm{~b}$ & $* * *$ & $30,000[34]$ \\
\hline 1-octanol & $150.12 a$ & $120.1 b$ & $* * *$ & $180.7 \mathrm{a}$ & $125.2 b$ & $* * *$ & $120[34]$ \\
\hline Phenylethyl Alcohol & $90.45 a$ & $60.03 b$ & $* * *$ & $70.85 a$ & $50.74 \mathrm{~b}$ & $* * *$ & $10,000[34]$ \\
\hline Geraniol & $6.5 a$ & $5.2 \mathrm{~b}$ & $*$ & $6.9 a$ & $3.12 b$ & $* *$ & $7[37]$ \\
\hline Citronellol & nd & $6.24 b$ & $*$ & $6.56 a$ & $6.81 \mathrm{a}$ & $\mathrm{ns}$ & $100[34]$ \\
\hline Linalool & $4 a$ & $4 \mathrm{a}$ & ns & $2 a$ & $3 b$ & $*$ & 15 [34] \\
\hline \multicolumn{8}{|c|}{ Esters } \\
\hline Ethyl hexanoate & $102.54 \mathrm{a}$ & $114.25 b$ & ** & $110.14 \mathrm{a}$ & $126.2 b$ & $* *$ & $5[34]$ \\
\hline Ethyl 2-methyl butyrate & $10.12 \mathrm{a}$ & $10.56 a$ & ns & $10.19 a$ & $14.15 b$ & $*$ & $18[34]$ \\
\hline Ethyl butyrate & $50.45 a$ & $48.42 \mathrm{~b}$ & $*$ & $51.11 \mathrm{a}$ & $52.1 \mathrm{~b}$ & $*$ & $20[34]$ \\
\hline Ethyl 3-methyl butyrate & $26.21 \mathrm{a}$ & $30.76 \mathrm{~b}$ & $*$ & $10.23 a$ & $27.71 b$ & $* *$ & $3[34]$ \\
\hline Ethyl octanoate & $400.29 a$ & $420.8 b$ & $* *$ & $200.19 a$ & $270.16 \mathrm{~b}$ & $* * *$ & $2[34]$ \\
\hline Ethyl decanoate & $150.5 a$ & $160.48 b$ & $* *$ & $115.62 a$ & $120.32 b$ & $* *$ & $200[38]$ \\
\hline Ethyl benzoate & $170.52 \mathrm{a}$ & $140.43 b$ & $* * *$ & $90.17 \mathrm{a}$ & $60.36 b$ & $* * *$ & $575[38]$ \\
\hline \multicolumn{8}{|c|}{ Acetates } \\
\hline Hexyl acetate & $180.11 \mathrm{a}$ & $180.33 a$ & ns & nd & nd & - & $670[39]$ \\
\hline Ethyl acetate & $70.12 a$ & $80.26 b$ & $* *$ & $50.48 a$ & $70.78 b$ & $* * *$ & $32,600[40]$ \\
\hline 2-Phenethyl acetate & $350.19 a$ & $150.35 b$ & $* * *$ & $400.51 \mathrm{a}$ & $170.19 b$ & $* * *$ & $250[34]$ \\
\hline Isoamyl acetate & $126.14 a$ & $107.23 b$ & $* * *$ & 105.1a & $106.5 b$ & $* *$ & $30[34]$ \\
\hline \multicolumn{8}{|c|}{ Aldehyde } \\
\hline Vanillin aldehyde & nd & $10.4 \mathrm{~b}$ & $*$ & nd & nd & - & $26[41]$ \\
\hline \multicolumn{8}{|c|}{ Acids } \\
\hline Hexanoic acid & $3458 \mathrm{a}$ & $3488 b$ & $* *$ & $4120 a$ & $4137 \mathrm{~b}$ & $* *$ & $3000[34]$ \\
\hline Phenylacetic acid & $560 \mathrm{a}$ & $500 \mathrm{~b}$ & $* *$ & $600 a$ & $480 \mathrm{~b}$ & $* * *$ & $10,000[34]$ \\
\hline Octanoic acid & $1110 \mathrm{a}$ & $1112 b$ & $*$ & $1000 \mathrm{a}$ & $1010 \mathrm{~b}$ & * & $7000[34]$ \\
\hline \multicolumn{8}{|c|}{ Phenols } \\
\hline 4-vinylphenol & 9.47 & nd & * & 7.5 & nd & * & $180[42]$ \\
\hline 2-methoxy-4-inylphenol & $3.32 \mathrm{a}$ & $2.36 b$ & $* *$ & 1.3 & nd & * & $9.5[43]$ \\
\hline Eugenol & $5.15 \mathrm{a}$ & $3.17 \mathrm{~b}$ & $* * *$ & 1.4 & nd & * & $6[38]$ \\
\hline
\end{tabular}

$\mathrm{a}, *, * *, * * *$, ns: significant at $p \leq 0.05,0.01$, and 0.001 , or not significant, respectively; nd-not detected. Treatments with the same letter within a row are not significantly different; $p \leq 0.05$, least significant difference. 
Statistical analysis showed that most of aromatic compounds with the exception of geraniol, citronellol, linalool, and ethyl benzoate found in icewines from dark grapes had differences between harvests (Table 6). All aldehydes including furfural, benzaldehyde, vanillin aldehyde and acids such as hexanoic, phenylacetic, and octanoic acids had lower concentrations in icewines of $\mathrm{H} 1$ compared to $\mathrm{H} 2$. Citronellol and linalool were not detected in Marselan icewines made from H2. Furfural was found only in Moldova and Marselan icewines. Benzaldehyde was found only in Marselan icewines of both harvests. Lactone had one representative $-\gamma$-nonalactone-found in Moldova icewines. Ethel decanoate, eugenol, 2-methoxy-4-vinylphenol, and 4-vinylphenol, belonging to phenols, were not identified Marselan icewine made from both harvests.

Table 6. Quantitative data of aromatic compounds in Moldova and Marselan icewines.

\begin{tabular}{|c|c|c|c|c|c|c|c|}
\hline \multirow{2}{*}{ Compound } & \multicolumn{2}{|c|}{ Moldova } & \multirow{2}{*}{ Significance $^{a}$} & \multicolumn{2}{|c|}{ Marselan } & \multirow{2}{*}{ Significance ${ }^{a}$} & \multirow{2}{*}{ Threshold $(\mu \mathrm{g} / \mathrm{L})$} \\
\hline & H1 & $\mathrm{H} 2$ & & H1 & $\mathrm{H} 2$ & & \\
\hline \multicolumn{8}{|c|}{ Higher and terpene alcohols } \\
\hline 1-Hexanol & $1200.15 a$ & $1110.52 b$ & $* * *$ & $1220.45 a$ & $1110.67 \mathrm{~b}$ & $* * *$ & $8000[34]$ \\
\hline Isobutanol & $1020.24 a$ & $2010 b$ & $* * *$ & $1550.17 \mathrm{a}$ & $2010.26 b$ & $* * *$ & $40,000[34]$ \\
\hline 1-Propanol & $130.19 a$ & $129.47 \mathrm{~b}$ & * & $130.8 \mathrm{a}$ & $128.4 b$ & * & $120[34]$ \\
\hline 1-Octen-3-ol & $2.4 \mathrm{a}$ & $3.0 \mathrm{~b}$ & * & $2.3 \mathrm{a}$ & $5.2 b$ & $* *$ & 1 [35] \\
\hline$\alpha$-Terpineol & $10.15 a$ & $12.27 \mathrm{~b}$ & $*$ & $20.75 a$ & $26.43 b$ & $* *$ & $250[36]$ \\
\hline Benzyl alcohol & $10.37 a$ & $20.96 b$ & $* *$ & $50.81 \mathrm{a}$ & $57.18 \mathrm{~b}$ & $* *$ & $10,000[34]$ \\
\hline Isoamyl alcohol & $200 a$ & $80 \mathrm{~b}$ & $* * *$ & $100 \mathrm{a}$ & $200 \mathrm{~b}$ & $* * *$ & $30,000[34]$ \\
\hline 1-octanol & 120 & nd & $* *$ & $121 \mathrm{a}$ & $120 \mathrm{~b}$ & $* * *$ & $120[34]$ \\
\hline Phenylethyl Alcohol & $10.76 \mathrm{a}$ & $30.72 b$ & $* * *$ & $10.4 \mathrm{a}$ & $50.81 b$ & $* *$ & $10,000[34]$ \\
\hline Geraniol & $4.47 \mathrm{a}$ & $5.5 \mathrm{~b}$ & $* *$ & $4.13 a$ & $4.17 \mathrm{a}$ & ns & $7[37]$ \\
\hline Citronellol & 1.61 & nd & $*$ & 2.45 & nd & $*$ & $100[34]$ \\
\hline Linalool & $3.2 \mathrm{a}$ & $3.24 \mathrm{a}$ & ns & 2.25 & nd & * & $15[34]$ \\
\hline \multicolumn{8}{|c|}{ Esters } \\
\hline Ethyl hexanoate & $123.11 \mathrm{a}$ & $159.19 b$ & $* * *$ & $137.75 a$ & $164.19 \mathrm{~b}$ & $* * *$ & $5[34]$ \\
\hline Ethyl 2-methyl butyrate & $11.9 a$ & $15.1 b$ & $* *$ & $25.5 a$ & $15.4 b$ & $* * *$ & 18 [34] \\
\hline Ethyl butyrate & $60.52 \mathrm{a}$ & $30.63 b$ & $* * *$ & $45.31 \mathrm{a}$ & $15.24 b$ & $* * *$ & $20[34]$ \\
\hline Ethyl 3-methyl butyrate & $13.7 \mathrm{a}$ & $12.61 \mathrm{~b}$ & $* *$ & $11.28 \mathrm{a}$ & $9.17 \mathrm{~b}$ & $* * *$ & $3[34]$ \\
\hline Ethyl octanoate & $75.13 a$ & $91.64 b$ & $* * *$ & $84.14 a$ & $92.97 \mathrm{~b}$ & $* * *$ & $2[34]$ \\
\hline Ethyl decanoate & $115.52 a$ & $130.71 b$ & $* * *$ & nd & nd & - & $200[38]$ \\
\hline Ethyl benzoate & $20.1 \mathrm{a}$ & $20.15 a$ & ns & $80.75 a$ & $25.84 \mathrm{~b}$ & $* * *$ & 575 [38] \\
\hline \multicolumn{8}{|c|}{ Acetates } \\
\hline Hexyl acetate & $210.7 \mathrm{a}$ & $280.24 b$ & $* * *$ & $180.79 a$ & $200.8 b$ & $* * *$ & $670[39]$ \\
\hline Ethyl acetate & nd & nd & - & $35.17 a$ & $38.93 b$ & $* *$ & $32,600[40]$ \\
\hline 2-Phenethyl acetate & $250.52 a$ & $245.78 b$ & $* * *$ & $263.87 a$ & $219.14 b$ & $* * *$ & $250[34]$ \\
\hline Isoamyl acetate & $104.47 \mathrm{a}$ & $100.55 b$ & $* *$ & $110.64 a$ & $105.37 \mathrm{~b}$ & * & $30[34]$ \\
\hline \multicolumn{8}{|c|}{ Aldehyde } \\
\hline Furfural & $30.35 a$ & $50.47 \mathrm{~b}$ & $* * *$ & $10.15 a$ & $50.5 b$ & $* * *$ & $14,100[38]$ \\
\hline Benzaldehyde & nd & nd & - & $6.17 \mathrm{a}$ & $10.87 \mathrm{~b}$ & $* * *$ & $2000[44]$ \\
\hline Vanillin aldehyde & $12.14 \mathrm{a}$ & $15.15 b$ & * & nd & $6.37 \mathrm{~b}$ & $*$ & $26[41]$ \\
\hline \multicolumn{8}{|c|}{ Acids } \\
\hline Hexanoic acid & $3205.23 a$ & $3240.51 b$ & $* * *$ & $3140.62 \mathrm{a}$ & $3170.74 b$ & $* * *$ & $3000[34]$ \\
\hline Phenylacetic acid & $640.63 a$ & $410.74 b$ & $* * *$ & $510.49 a$ & $520.81 b$ & $* * *$ & $10,000[34]$ \\
\hline Octanoic acid & $650.54 a$ & $660.78 b$ & $* *$ & $580.91 \mathrm{a}$ & $600.62 b$ & $* * *$ & $7000[34]$ \\
\hline \multicolumn{8}{|c|}{ Lactone } \\
\hline$\gamma$-nonalactone & $40.14 \mathrm{a}$ & $41.96 \mathrm{~b}$ & * & nd & nd & - & $30[38]$ \\
\hline \multicolumn{8}{|c|}{ Phenols } \\
\hline 4-vinylphenol & 4.36 & nd & $*$ & nd & nd & - & 180 [42] \\
\hline 2-methoxy-4Vinylphenol & $4.54 \mathrm{a}$ & $2.69 b$ & $* *$ & nd & nd & - & 9.5 [43] \\
\hline Eugenol & $1.5 \mathrm{a}$ & $2.13 b$ & $*$ & nd & nd & - & 6 [38] \\
\hline
\end{tabular}

$\mathrm{a}, *, * * * * *$, ns: significant at $p \leq 0.05,0.01$, and 0.001 , or not significant, respectively; nd-not detected. Treatments with the same letter within a row are not significantly different; $p \leq 0.05$, least significant difference. 


\section{Discussion}

\subsection{Must and Wine Chemical Analysis}

Analysis of the scientific literature showed that the sugar and alcohol contents of icewines differ significantly between producers and countries. Canadian icewines contain 9-12\% alcohol and 170-240 g/L of sugar, while wines from Germany and other European countries have $7-10 \%$ alcohol and sugar of 150-200 g/L [34]. The physicochemical properties of the analyzed icewines showed differences in the sugar content of musts and residual sugar compared with the chemical attributes of Riesling, Vidal, and Cabernet franc icewines from Canada [21,22,24]. Such difference is especially associated with specific harvesting conditions. In addition, the peculiar change of the physicochemical properties of grapes is involved with its overripening after technological maturity. According to a study [45], in Vidal Blanc grapes from Canada during long-term ripening, the relationship between the mass concentrations of titrated acids and sugars was inversely proportional, which was also observed in our investigation. Thus, with increasing concentrations of sugars, acids decreased, which is probably due to the influence of climatic conditions on the physicochemical properties of grapes.

The fermentation of must with high sugar is known to have challenges to produce quality icewine. The main factor in choosing the yeast for icewine is the ability to accumulate a minimum content of volatile acids. For this reason, yeast strain Vin 2000, which is a hybrid, was chosen. The yeast used in the study belongs to the strain Saccharomyces cerevisiae, which produces acetic acid in response to the extreme osmotic stress caused by high sugar levels $[24,30]$. The quantity of acetic acid and glycerol and the total acidity correlate with the sugar concentration of musts [30], which was also investigated in icewines. The samples had higher values of VA compared to H1, perhaps due to the higher sugar of musts, that confirms the abovementioned statement.

\subsection{Sensory Analysis}

Icewines demonstrate a complex aroma formed by the quantity of aroma volatiles including esters, terpenes, norisoprenoids, alcohols, aldehydes, phenols, and lactones [33]. The sensory profiles of the experimental icewines from Ukraine consisted of typical descriptors (Figure 1) such as honey, tropical fruits, dried apricot, and raisin for white wines and red berries for icewines made from dark grapes [24,30]. All icewine samples were medium-bodied, full of sweet fruits in terms of aroma.

Rkatsiteli icewines were characterized by the pronounced aroma of dried apricot; honey and raisin contributed to the sweetness in taste. Icewines from $\mathrm{H} 1$ and $\mathrm{H} 2$ differed in the intensity of dried apricot, melon, pineapple, fig, lemon, honey, and raisin aromas $(p \leq 0.05)$. Aromas of pineapple and melon in icewine obtained from $\mathrm{H} 2$ were more intensive. In addition, the taste of sweetness and sourness varied. The varietal aroma with floral and citrus tones is specific to Rkatsiteli table wines [46] that significantly differ from the icewine style.

Icewines produced from Telti kuruk grapes had intense aromas of lemon and caramel. In addition, a lemon aroma with the highest score was determined in Gewürztraminer icewines [47]. Telti kuruk varietal table wines are distinguished by a delicate aroma of tropical fruits, fresh notes of eucalyptus, and mint [14]. Our investigations showed that the intensity of melon, pineapple, lemon, caramel, spicy, and oxidized aromas was significantly different between icewines of different harvests $(p \leq 0.05)$. In addition, oxidized aromas of these icewines were more noticeable compared to others, which may be related to relatively high values of VA, i.e., in Telti kuruk icewines- 0.85 and $1.0 \mathrm{~g} / \mathrm{L}$ in $\mathrm{H} 1$ and H2, respectively. No spicy, cherry, melon or plum was found in the icewine of H2. Aromas of raisin, honey, dried apricot, and sweetness were not different between Telti kuruk icewines. It should be mentioned Telti kuruk is a significant component of the autochthonous grape variety stock of Ukraine, as well as an important component of the genetic heritage of the domestic viticulture and wine industry. 
Aroma descriptors of dried apricot and honey were characteristic of Moldova icewines but they were not significant between icewines from $\mathrm{H} 1$ and $\mathrm{H} 2$. Melon and caramel aromas were not found by experts in wine from $\mathrm{H} 2$. According to the statistical method, the aroma intensity of raisin, fig, pineapple, plum, and cherry was significantly different between harvests $(p \leq 0.05)$. In addition, sourness and sweetness were different. There is limited scientific literature on wines made from Moldova grapes; therefore a comprehensive comparison is impossible to indicate further study of their usage and properties.

Today Marselan wines are interesting to researchers [48-50]. Aroma profiles of Marselan wines made by different wine technologies in Brazil consisted of plum, strawberry, red fruits, blackberry, cherry, tropical fruits, raisin, honey, and marmalade aromas. In addition, vegetable properties such as bell pepper, string bean, dry straw, with, broccoli, asparagus, cabbage, pepper, twig, and spicy aromatic descriptors including pepper, mint, clove, cinnamon, mushroom, nutmeg, fine herbs, vanilla, and chocolate occur in small quantities [48]. According to our observations, Marselan icewine of both harvests possessed plum, cherry, raisin, honey, and dried apricot aromas; however, in samples which had been produced from $\mathrm{H} 2$, these descriptors were more intense $(p \leq 0.05)$. The intensity of the oxidized aroma of icewines differed. In addition, melon and pineapple aromas as well as caramel were not inherent in Marselan icewines. General sweetness and sourness of these wines were determined to be similar to Moldova grapes and differed from white-skinned cultivars.

\subsection{Aroma Compounds}

The volatile composition of wine is known to depend on yeast strains [21,34,50], fermentation conditions [21,47,51], and grape variety [22,52]. Analysis of scientific information highlighted icewines from the harvest of Riesling grapes have many key aromatic compounds such as: 1-octen-3-ol, ethyl benzoate, ethyl octanoate, $\beta$-ionone, ethyl isobutyrate, ethyl 3-methylbutyrate, 1-hexanol, 1-octanol, cis-rose oxide, nerol oxide, ethyl phenylacetate, $\gamma$-nonalactone, and $\beta$-damascenone [22,30]. Isoamyl alcohol, 2-methyl-1-butanol, and 2-phenylethanol were found in Cabernet franc icewines [21].

\subsection{Higher and Terpene Alcohols}

The alcohol content differed both qualitatively and quantitatively among the icewines. The total concentration of the alcohols was from $3260 \mu \mathrm{g} / \mathrm{L}$ (isobutanol of Telti kuruk icewine of H2) to $1 \mu \mathrm{g} / \mathrm{L}$ (citronellol of Moldova icewine of H1). Some alcohols had higher concentrations including 1-octen-3-ol, 1-propanol, $\alpha$-terpineol, and benzyl alcohol; however, the latter was not detected in white icewines as well as 1-hexanol. The concentrations of such alcohols as 1-propanol, 1-octen-3-ol, 1-octanol, and geraniol exceeded the odor threshold and were identified below $300 \mathrm{mg} / \mathrm{L}$, which contributed to the aromas of the wine [52]. Isoamyl alcohol had a lower concentration range in the analyzed wines (80-560 mg/L) compared to Canadian icewines (36,235-90,860 mg/L); similar to linalool (average values of Ukrainian experimental icewines were $2-4 \mathrm{mg} / \mathrm{L}$ and in Canadian ones-64.6-75.9 mg/L). Linalool is included in monoterpenes that are important factors, forming the aroma of white wines made from Muscat varieties (Muscat of Alexandria, Muscat de Fronttignan) and Gewürztraminer and Riesling [53]. It should be noted that higher alcohols, including isoamyl and isobutyl alcohols, are synthesized from amino acids. Moreover, aromatic amino acids, including phenylalanine and tyrosine, produce aromatic alcohols (contributing to the following aromas: honey, spice, rose, lilac [54]), such as phenylethyl alcohol whose contents in the investigated icewines were lower than the odor threshold.

\subsection{Esters}

Ethyl hexanoate, ethyl octanoate, and ethyl decanoate had lower concentrations in all analyzed icewines produced from $\mathrm{H} 2$ contrary to those of H1. Taking into account that esters are usually considered products of yeast metabolism, we can suppose that the 
fermentation of grapes en picked in $\mathrm{H} 2$ was problematic for yeast due to a higher sugar content. The ester ethyl decanoate was not identified in Marselan icewines of both harvests as well as in table wines in a previous study [55].

There were three compounds above $100 \mu \mathrm{g} / \mathrm{L}$ among acetates. The contents of 2phenethyl acetate and isoamyl acetate were higher than the odor threshold and lower for $\mathrm{H} 2$ in all treatments. The concentrations of ethyl acetate were higher in wines produced from overripened grapes [56], which was also observed in our study on icewines of H2.

\subsection{Aldehydes, Acids, Lactones, and Phenols}

The composition of aldehydes, acids, lactones, and phenols differed both qualitatively and quantitatively among the icewines. The contents of aldehydes, lactones, and phenols were at extremely low values compared to other aromatic compounds. The concentrations of furfural ranged from 10 to $50 \mu \mathrm{g} / \mathrm{L}$ in wines from red cultivars [57], while benzaldehyde, characterized by an almond aroma, was identified in Marselan icewines of both harvests. $\gamma$-nonalactone as well as vanillin aldehyde were present only in Moldova icewines. The compound $\gamma$-nonalactone with aromas of oil-flower, honey, and coconut is one of the main odor impact components in sweet Fiano wine [58]. In addition, some scientists have considered that the mass concentration of $\gamma$-nonalactone relates to notes of prunes, as the aroma of aging red wines, while other researchers reported a correlation between $\gamma$ - and $\delta$-lactones and the aroma of botrytized wines from Sauternes, Barsac, Lupiak [59], and Hungary (Tokay Asu) [60].

Octanoic, phenylacetic, and hexanoic acids were detected and quantified in all wine samples. The contents of acids in icewines made from $\mathrm{H} 2$ were higher than those from $\mathrm{H} 1$ but only concentrations of hexanoic acid were above $3000 \mu \mathrm{g} / \mathrm{L}$. Fatty acids are produced in the lipid metabolism of yeast [61].

Phenols including 4-vinylphenol, 2-methoxy-4-vinylphenol, and eugenol tended to have the highest levels from H1 in Rkatsiteli and Moldova icewines of both harvests and Telti kuruk from H1. The compound eugenol is responsible for clove and oak aromas, described in wines made using oak chips [62]. Undesirable parts of grapes such as grape stalks may occur in fermented musts.

In addition, no concentrations of cis-rose oxide, nerol oxide, and $\beta$-damascenone were identified in the current work that had been suggested as the important odorants in icewines from Riesling and Vidal [22,63]. It is worth pointing out that contents of $\beta$-damascenone were also investigated in beer [64] and aged Riesling wines [65,66]. On this basis, the aromatic compounds of experimental icewines produced under the climate conditions in the south of Ukraine have their own quantitative and qualitative compositions that depend on the grape varieties used.

\section{Conclusions}

This study demonstrates that sensory descriptors and aromatic compounds of icewines produced from Rkatsiteli, Telti kuruk, Moldova, and Marselan grapes grown in the Odessa region differed depending on the harvest date. The experimental wines were characterized by aromas of dried apricot, raisin, honey, and oxidized aromas. Marselan and Moldova icewines were evaluated as more intense in cherry and plum aromas, whereas pineapple and melon aromas were more intense in Rkatsiteli and Telti kuruk icewines. Icewines produced from different grape cultivars from different harvests varied in volatile aromatic compounds. Some compounds had higher concentrations in wines of H2, especially 1octen-3-ol, 1-propanol, $\alpha$-terpineol and benzyl alcohol, hexanoic acid, ethyl hexanoate, ethyl acetate, ethyl octanoate, and octanoic acid. Icewines from white grape cultivars did not have 1-hexanol and benzyl alcohol that were found in dark-skinned grape varieties. Marselan icewines were the only ones containing benzaldehyde, but $\gamma$-nonalactone occurred only in Moldova wines. Further work could focus on investigations on the influence of different yeast strains on the aromatic compounds in icewines made from Rkatsiteli, Telti kuruk, Moldova, and Marselan grapes. 
Author Contributions: I.M.-Formal analysis, Funding acquisition, Investigation. V.L.-Methodology, Validation. All authors have read and agreed to the published version of the manuscript.

Funding: This research received no external funding.

Informed Consent Statement: Informed consent was obtained from all subjects involved in the study.

Acknowledgments: The authors sincerely thank the reviewers for their constructive comments.

Conflicts of Interest: The authors declare no conflict of interest.

\section{References}

1. VQA Ontario. Available online: http://www.vqaontario.com/Regulations/Standards (accessed on 15 September 2020).

2. Special Wines. 4.1 Basic definition (6/76). International Code of Oenological Practices. OIV Code Sheet. Issue 2015/01. Available online: http://www.oiv.int/public/medias/7213/oiv-international-code-of-oenological-practices-2020-en.pdf (accessed on 15 September 2020).

3. Bezhuashvili, M.; Tskhvedadze, L.; Surguladze, M.; Shoshiashvili, G.; Kharadze, S.; Gagunashvili, L.; Vashakidze, P. Stressmetabolitesphytoalexins-stilbenoids of grape skin Rkatsiteli variety (Vitisvinifera L.) in condition gray mildew. Eurasian J. Biosci. 2019, 13, 549-554.

4. Ostapenko, V.; Tkachenko, O.; Iukuridze, E. Sensory and chemical attributes of dessert wines made by different freezing methods of Marselan grapes. Ukr. Food J. 2017, 6, 278-290. [CrossRef]

5. INRA. 2020. Available online: http://www7.inra.fr/internet/Directions/DIC/ACTUALITES/DOSSIERS/qualite-aliments/vincepage- $\backslash \mathrm{T} 1 \backslash$ textquoterightMarselan $\backslash \mathrm{T} 1 \backslash$ textquoteright.htm (accessed on 15 September 2020).

6. Ostapenko, V.; Kameneva, N. Suitability of the technical grape variety of the Northern Black Sea Coast in the traditional production for "Icewine". Ukr. Food J. 2017, 6, 727-737. [CrossRef]

7. Ostapenko, V. Analysis on application of different grape varieties in the production of icewine. A review. Ukr. Food J. 2016, 5, 678-694. [CrossRef]

8. Moriondo, M.; Jones, G.V.; Bois, B.; Dibari, C.; Ferrise, R.; Trombi, G.; Bindi, M. Projected shifts of wine regions in response to climate change. Clim. Chang. 2013, 119, 825-839. [CrossRef]

9. Van Leeuwen, C.; Darriet, P. The impact of climate change on viticulture and wine quality. J. Wine Econ. 2016, 11, 150-167. [CrossRef]

10. Santillán, D.; Iglesias, A.; La Jeunesse, I.; Garrote, L.; Sotes, V. Vineyards in transition: A global assessment of the adaptation needs of grape producing regions under climate change. Sci. Total Environ. 2019, 657, 839-852. [CrossRef]

11. Cardell, M.F.; Amengual, A.; Romero, R. Future effects of climate change on the suitability of wine grape production across Europe. Reg. Environ. Chang. 2019, 19, 2299-2310. [CrossRef]

12. Tkachenko, O.; Bilko, M.; Ostryk, A.; Ostapenko, V. Regulation of icewine production in the world. In Proceedings of the Youth Scientific Achievements to the 21st Century Nutrition Problem Solution: Collection of Abstracts of 83 International Scientific Conference of Young Scientists and Students, Kyiv, Ukraine, 5-6 April 2017.

13. Cyr, D.; Kusy, M. Canadian ice wine production: A case for the use of weather derivatives. J. Wine Econ. 2007, 2, 145-167. [CrossRef]

14. Tkachenko, O.B.; Trinkal, O.V. The aroma peculiarities of some white wines from autochthonous grapes varieties from Western Europe and Ukraine. East. Eur. J. Enterp. Technol. 2015, 10, 40-45. [CrossRef]

15. Tkachenko, O.B.; Trinkal, O.V.; Pashkovski, A.I. The influence of agrometeorological conditions of the vegetation period on the technological properties of grapes. Technol. Audit Prod. Reserves 2015, 3, 18-21. [CrossRef]

16. Reynolds, A.G. Managing Wine Quality. In Oenology and Wine Quality; Woodhead Publishing: Oxford, UK, 2010 ; Volume 2.

17. Lukić, I.; Radeka, S.; Grozaj, N.; Staver, M.; Peršurić, Đ. Changes in physico-chemical and volatile aroma compound composition of Gewürztraminer wine as a result of late and ice harvest. Food Chem. 2016, 196, 1048-1057. [CrossRef] [PubMed]

18. Lan, Y.-B.; Qian, X.; Yang, Z.-J.; Xiang, X.-F.; Yang, W.-X.; Liu, T.; Zhu, B.-Q.; Pan, Q.-H.; Duan, C.-Q. Striking changes in volatile profiles at sub-zero temperatures during over-ripening of 'Beibinghong' grapes in Northeastern China. Food Chem. 2016, 212, 172-182. [CrossRef] [PubMed]

19. Huang, L.; Ma, Y.; Tian, X.; Li, J.-M.; Li, L.-X.; Tang, K.; Xu, Y. Chemosensory characteristics of regional Vidal icewines from China and Canada. Food Chem. 2018, 261, 66-74. [CrossRef] [PubMed]

20. Ma, Y.; Tang, K.; Xu, Y.; Li, J.M. Characterization of the key aroma compounds in Chinese Vidal icewine by gas chromatographyolfactometry, quantitative measurements, aroma recombination, and omission tests. J. Agric. Food Chem. 2017, 65, 394-401. [CrossRef]

21. Synos, K.; Reynolds, A.G.; Bowen, A.J. Effect of yeast strain on aroma compounds in Cabernet franc icewines. Lwt-Food Sci. Technol. 2015, 64, 227-235. [CrossRef]

22. Bowen, A.J.; Reynolds, A.G. Odor potency of aroma compounds in Riesling and Vidal blanc table wines and icewines by gas chromatography-olfactometry-mass spectrometry. J. Agric. Food Chem. 2012, 60, 2874-2883. [CrossRef] 
23. Crandles, M.; Reynolds, A.G.; Khairallah, R.; Bowen, A. The effect of yeast strain on odor active compounds in Riesling and Vidal blanc icewines. Lwt-Food Sci. Technol. 2015, 64, 243-258. [CrossRef]

24. Nurgel, C.; Pickering, G.J.; Inglis, D.L. Sensory and chemical characteristics of Canadian ice wines. J. Sci. Food Agric. 2004, 84, 1675-1684. [CrossRef]

25. Clary, C.; Gamache, A.; Cliff, M.; Fellman, J.; Edwards, C. Flavor and Aroma attributes of Riesling wines produced by freeze concentration and microwave vacuum dehydration. J. Food Process. Preserv. 2006, 30, 393-406. [CrossRef]

26. Lutskova, V.A. Development of Icewine Technology in the Agricultural Climatic Conditions of the Northern Black Sea Coast. Ph.D. Thesis, Kyiv National University of food Technologies, Kyiv, Ukraine, 4 December 2019. Available online: https: / drive. google.com/file/d/1tCXnzFCpXn0t1JoFJjPBlYCwY9p-7WCy/view (accessed on 29 September 2020).

27. TC U 37471967-11.02.11. In Technological Instructions for the Processing of Wine Materials at the Enterprises of the Wine Industry; Ministry of Agrarian Policy and Food of Ukraine: Kyiv, Ukraine, 2014.

28. Compendium of International Methods of Wine and Must Analysis; International Organisation of Vine and Wine: Paris, France, 2016; Volume 1, pp. 64-65.

29. Zoecklein, B.W.; Fugelsang, K.C.; Gump, B.H.; Nury, F.S. Volatile acidity. In Wine Analysis and Production; Springer: Boston, MA, USA, 1995; pp. 192-198.

30. Noble, A.C.; Arnold, R.A.; Masuda, B.M.; Pecore, S.D.; Schmidt, J.O.; Stern, P.M. Progress towards a standardized system of wine aroma terminology. Am. J. Enol. Vitic. 1984, 35, 107-109.

31. Jackson, R.S. Wine Tasting A Professional Handbook; Academic Press: London, UK, 2002.

32. Romashkina, G.F.; Tatarova, G.G. Concording coefficient in sociological data analysis. Sociology 2005, 20, 131-158.

33. Jing, W.; Min, L.; Jixin, L.; Tengzhen, M.; Shunyu, H.; Morata, A.; Lepe, J.A.S. Biotechnology of ice wine production. In Advances in Biotechnology for Food Industry; Academic Press: Cambridge, MA, USA, 2018; pp. 267-300.

34. Guth, H. Identification of character impact odorants of different white wine varieties. J. Agric. Food Chem. 1997, 45, 3022-3026. [CrossRef]

35. Buttery, B.G.; Turnbaugh, J.G.; Ling, L.C. Contribution of volatiles to rice aroma. J. Agric. Food Chem. 1988, 36, 1006-1009. [CrossRef]

36. Pérez-López, A.J.; Carbonell-Barrachina, Á.A. Volatile odour components and sensory quality of fresh and processed mandarin juices. J. Sci. Food Agric. 2006, 86, 2404-2411. [CrossRef]

37. Takoi, K.; Koie, K.; Itoga, Y.; Katayama, K.; Shimase, M.; Nakayama, Y.; Watari, J. Biotransformation of hop-derived monoterpene alcohols by lager yeast and their contribution to the flavor of hopped beer. J. Agric. Food Chem. 2010, 58, 5050-5058. [CrossRef]

38. Ferreira, V.; Lopez, R.; Cacho, J. Quantitative determination of the odorants of young red wines from different grape varieties. J. Sci. Food Agric. 2000, 80, 1659-1667. [CrossRef]

39. Franco, M.; Peinado, R.; Medina, M.; Moreno, J. Off-vine grape drying effect on volatile compounds and aromatic series in must from Pedro Ximenez grape variety. J. Agric. Food Chem. 2004, 52, 3905-3910. [CrossRef]

40. Gao, W.; Fan, W.; Xu, Y. Characterization of the key odorants in light aroma type Chinese liquor by gas chromatographyolfactometry, quantitative measurements, aroma recombination, and omission studies. J. Agric. Food Chem. 2014, 62, 5796-5804. [CrossRef]

41. Jin, B.; Wang, D.; Xu, Y.; Zhao, G. Study on olfactory thresholds for several aroma components in Chinese rice wine. Sci. Technol. Food Ind. 2012, 33, 35-138.

42. López, R.; Aznar, M.; Cacho, J.; Ferreira, V. Determination of minor and trace volatile compounds in wine by solid-phase extraction and gas chromatography with mass spectrometric detection. J. Chromatogr. 2002, 966, 167-177. [CrossRef]

43. Saenz-Navajas, M.P.; Campo, E.; Cullere, L.; Fernandez-Zurbano, P.; Valentin, D.; Ferreira, V. Effects of the nonvolatile matrix on the aroma perception of wine. J. Agric. Food Chem. 2010, 58, 5574-5585. [CrossRef] [PubMed]

44. Etiévant, P.X. Wine. In Volatile Compounds in Foods and Beverages; Maarse, H., Ed.; Marcel Dekker: New York, NY, USA, 1991; Volume 14, pp. 483-546.

45. Gallander, G. Effect of Grape Maturity on the Composition and Quality of Ohio Vidal Blanc Wines. Am. J. Enol. Vitic. 1983, 34, 139-141.

46. Gulua, L.; Nikolaishvili, L.; Turmanidze, T.; Jgenti, M.; Bezhuashvili, M.; FitzGerald, R. Chemical constituents, antioxidant and anti-lipase activity of the selected wines produced in Georgia. Ukr. Food J. 2018, 7, 177-191. [CrossRef]

47. Zhan, J.C. Wine Grape Varieties; China Agricultural University: Beijing, China, 2010; Chapter 4; pp. 85-106.

48. Pozzatti, M.; Guerra, C.; Martins, G.; dos Santos, I.; Wagner, R.; Ferrão, M.; Manfroi, V. Effects of winemaking on 'Marselan' red wines: Volatile compounds and sensory aspects. Ciência E Técnica Vitivinic. 2020, 35, 63-75. [CrossRef]

49. Lu, Y.; Sun, F.; Wang, W.; Liu, Y.; Wang, J.; Sun, J.; Gao, Z. Effects of spontaneous fermentation on the microorganisms diversity and volatile compounds during Marselan from grape to wine. Food Sci. Technol. 2020, 134, 110193. [CrossRef]

50. Dos Santos, C.E.; Debastiani, R.; Souza, V.S.; Peretti, D.E.; Jobim, P.F.; Yoneama, M.L.; Dias, J.F. The influence of the winemaking process on the elemental composition of the Marselan red wine. J. Sci. Food Agric. 2019, 99, 4642-4650. [CrossRef]

51. Tao, Y.; Li, H.; Wang, H.; Zhang, L. Volatile compounds of young Cabernet Sauvignon red wine from Changli County (China). J. Food Compos. Anal. 2008, 21, 689-694. [CrossRef]

52. Rapp, A.; Mandery, H. Wine aroma. Experientia 1986, 42, 873-884. [CrossRef]

53. Francis, I.L.; Newton, J.L. Determining wine aroma from compositional data. Aust. J. Grape Wine Res. 2005, 11, 114-126. [CrossRef] 
54. Lyu, J.; Ma, Y.; Xu, Y.; Nie, Y.; Tang, K. Characterization of the key aroma compounds in Marselan wine by gas chromatographyolfactometry, quantitative measurements, aroma recombination, and omission tests. Molecules 2019, 24, 2978. [CrossRef] [PubMed]

55. Tkachenko, O.B.; Trinkal, O.V. Chemistry of wine aromas. Food Sci. Technol. 2015, 1, 42-50. [CrossRef]

56. Bindon, K.; Varela, C.; Kennedy, J.; Holt, H.; \& Herderich, M. Relationships between harvest time and wine composition in Vitis vinifera L. cv. Cabernet Sauvignon 1. Grape and wine chemistry. Food Chem. 2013, 138, 1696-1705. [CrossRef] [PubMed]

57. Ruiz, M.J.; Zea, L.; Moyano, L.; Medina, M. Aroma active compounds during the drying of grapes cv. Pedro Ximenez destined to the production of sweet Sherry wine. Eur. Food Res. Technol. 2010, 230, 429-435. [CrossRef]

58. Genovese, A.; Gambuti, A.; Piombino, P.; Moio, L. Sensory properties and aroma compounds of sweet Fiano wine. Food Chem. 2007, 103, 1228-1236. [CrossRef]

59. Sarrazin, E.; Dubourdieu, D.; Darriet, P. Characterization of key-aroma compounds of botrytized wines, influence of grape botrytization. Food Chem. 2007, 103, 536-545. [CrossRef]

60. Miklósy, É.; Kerényi, Z. Comparison of the volatile aroma components in noble rotted grape berries from two different locations of the Tokaj wine district in Hungary. Anal. Chim. Acta 2004, 513, 177-181. [CrossRef]

61. Patel, S.; Shibamoto, T. Effect of 20 different yeast strains on the production of volatile components in Symphony wine. J. Food Compos. Anal. 2003, 16, 469-476. [CrossRef]

62. Arapitsas, P.; Antonopoulos, A.; Stefanou, E.; Dourtoglou, V.G. Artificial aging of wines using oak chips. Food Chem. 2004, 86, 563-570. [CrossRef]

63. Bowen, A.J.; Reynolds, A.G. Aroma compounds in Ontario Vidal and Riesling icewines. I. Effects of harvest date. Food Res. Int. 2015, 76, 540-549. [CrossRef]

64. Chevance, F.; Guyot-Declerck, C.; Dupont, J.; Collin, S. Investigation of the $\beta$-damascenone level in fresh and aged commercial beers. J. Agric. Food Chem. 2002, 50, 3818-3821. [CrossRef]

65. Winterhalter, P.; Gök, R. TDN and $\beta$-Damascenone: Two important carotenoid metabolites in wine. In Carotenoid Cleavage Products; American Chemical Society: Washington, DC, USA, 2013; pp. 125-137.

66. Khairallah, R.; Reynolds, A.G.; and Bowen, A.J. Harvest date effects on aroma compounds in aged Riesling icewines. J. Sci. Food Agric. 2016, 96, 4398-4409. [CrossRef] [PubMed] 